\title{
Studies on the Biosynthesis of Cholesterol
}

\section{BIOSYNTHESIS OF SQUALENE FROM DL-3-HYDROXY-3-METHYL- [2-14 C]PENTANO-5-LACTONE*}

\author{
By J. W. CORNFORTH, RITA H. CORNFORTH \\ (National Institute for Medical Research, Mill Hill, London, N.W. 7) \\ G. POPJÁK AND IRENE YOUHOTSKY GORE \\ (M.R.C. Experimental Radiopathology Research Unit, Hammersmith Hospital, \\ Ducane Road, London, W. 12)
}

(Received 22 November 1957)

Studies of the biosynthesis of squalene and of cholesterol from acetate in recent years have indicated the formation from acetate of a branchedchain intermediate ('isoprenoid unit') with an isopentane skeleton (Würsch, Huang \& Bloch, 1952; Cornforth, Hunter \& Popják, 1953; Cornforth \& Popják, 1954; Cornforth, Gore \& Popják, 1957) in the synthesis of the triterpene and sterol. The nature of this intermediate eluded detection, although the discovery of the biosynthesis of 3hydroxy-3-methylglutaric acid from acetate and acetoacetate by Rudney (1954) and by Bachhawat, Robinson \& Coon (1954) raised high hopes that this acid, or some other substance derived from it, might prove to be the intermediate much sought after. These hopes were not fulfilled. As the work of Coon and his colleagues showed (Bachhawat et al. 1954, 1955, 1956; Coon, Robinson \& Bachhawat, 1955; Coon, 1955), 3-hydroxy-3-methylglutaric acid is in rapid equilibrium in various biological systems with 3-methylcrotonic, 3-hydroxyisovaleric and 3-methylglutaconic acids as well as with acetyland acetoacetyl-coenzyme A. Any attempt therefore at labelling any of these branched acids with a carbon isotope in a specific position led to a redistribution of the label and no unequivocal evidence could be obtained to show whether or not an isopentane skeleton derived from any of these branched acids entered as a whole the cholesterol molecule. Adamson \& Greenberg (1957) excluded by a careful study all the above-named branched acids, with the possible exception of 3-methylglutaconic acid, as intermediates in the biosynthesis of cholesterol. Their article contains the references to previous work on this question.

Skeggs et al. (1956) discovered in distiller's soluble residues a growth factor for Lactobacillus acidophilus requiring acetate for its growth. The new factor was able to replace acetate in the incu-

* Part 4: Cornforth, Gore \& Popjảk (1957). bation medium. This substance was identified (Wolf et al. 1956, 1957) as the optically active 3hydroxy-3-methylpentano-5-lactone; the parent acid was named mevalonic acid (Wolf et al. 1957). No distinction has been drawn between the acid and its lactone in their utilization by biological systems; it is reasonable to suppose that hydrolysis of lactone to acid in such systems would be rapid. The acid bears a close chemical relationship to 3-hydroxy-3-methylglutaric acid: this relationship prompted Tavormina, Gibbs \& Huff (1956) to test mevalonic acid labelled with ${ }^{14} \mathrm{C}$ as a possible intermediate in cholesterol synthesis. They found that liver preparations converted the synthetic DL-mevalonic acid, labelled in position 2, into cholesterol with an efficiency of $43 \%$. The carboxyl carbon (C-1) of mevalonic acid was eliminated as carbon dioxide (Tavormina \& Gibbs, 1956).

These observations suggested that mevalonic acid gives rise directly to a branched-chain $\mathrm{C}_{5}$ intermediate, which, without participating in side reactions, is used in the biosynthesis of squalene and sterols. We thought that this idea could be tested by ascertaining first whether mevalonic acid was a carbon source for the synthesis of squalene or not, and if so, by determining the arrangement of the carbon atoms of mevalonic acid in the squalene molecule. The work reported here bears on these questions.

A method suitable for the synthesis of ${ }^{14} \mathrm{C}$ labelled mevalonic acid had not been reported by the American workers until after completion of the present experiments (Hoffman et al. 1957); a method developed independently is therefore included. In addition a number of other substances, related chemically to mevalonic acid, labelled with ${ }^{14} \mathrm{C}$ were made and tested as possible intermediates in sterol synthesis; the results with these substances are mentioned in the Discussion. Some of the results have already been reported briefly (Cornforth, Cornforth, Popják \& Gore, 1957). 
<smiles>CC(=O)CCO</smiles><smiles>COCCOCCO</smiles>

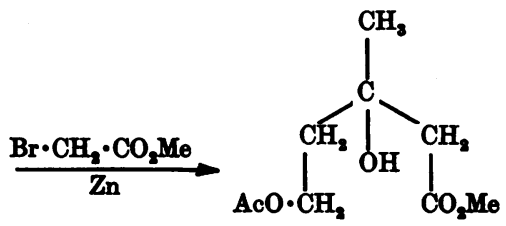<smiles>CCOCC(C)=CC(=O)O</smiles><smiles>CC1=CC(=O)OCC1</smiles><smiles>[Mg]O[Mg][Te]</smiles>

(III)

(II)<smiles>C=CC(=CC(=O)O)CCCC(=O)O</smiles>

KHSO,<smiles>CC12CCOC(=O)C1(O)C2</smiles>

(I)<smiles>C=CC(C)=O</smiles>

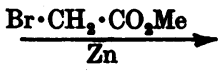<smiles>C=CC(C)(O)CC(O)OC(C)=O</smiles><smiles>C=CC(C)(O)CC(=O)O</smiles>

(V)

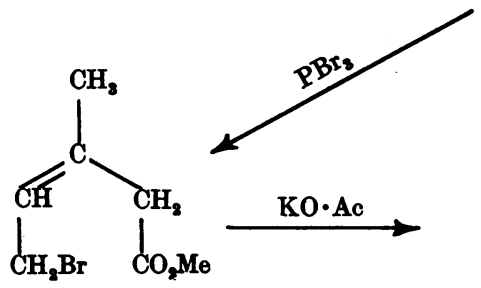<smiles>CC(=O)CC(C)=CCOC(C)=O</smiles><smiles>C=CC(C)=CC(=O)O</smiles>
(VI)<smiles>CC(=CC(=O)O)CC(=O)O</smiles><smiles>CC(=CCO)CC(=O)O</smiles>

(cis and trans)

Scheme 1. General outline of synthesis of mevalonic lactone and of related substances. 


\section{METHODS AND MATERIAL}

Preparation of DL-3-hydroxy-3-methyl-[2-14C]pentano-5lactone $\left(\left[2-{ }^{14} \mathrm{C}\right]\right.$ mevalonic acid $)$ and of other labelled substances. Scheme 1 gives the general outline of the syntheses carried out; the details are given at the end of the paper. The substances (all labelled with ${ }^{14} \mathrm{C}$ in position 2) tested were: 3-hydroxy-3-methylpentano-5-lactone (I); 3-methylpent2-eno-5-lactone (II) and the cis-acid (III) derived from it; cis-3-methylpenta-2:4-dienoic acid (IV); 3-hydroxy-3methylpent-4-enoic acid (V); 3-methylpenta-2:4-dienoic acid (mixture of cis and trans; VI); and 5-hydroxy-3methylpent-3-enoic acid (mixture of cis and trans; VII).

Preparation of liver homogenates. The livers of young rats (100-160 g. weight), anaesthetized with ether, were cut out and chilled in ice. After the organs had been wiped clean of blood, the livers were pressed through a stainless-steel barrel fitted with a piston and with a perforated plate at its end; the holes in this plate were of $1.5 \mathrm{~mm}$. diameter. The liver pulp thus obtained was free from connective tissue, blood vessels and bile ducts, these having been retained on the inside of the perforated plate. Homogenates were made from this pulp according to Bucher \& McGarrahan (1956) in a large Potter-Elvehjem type of homogenizer fitted with a nylon piston the diameter of which was $0.4 \mathrm{~mm}$. less than that of the glass barrel. For each $10 \mathrm{~g}$. of liver pulp $25 \mathrm{ml}$. of a $0 \cdot 1 \mathrm{M}$-potassium phosphate buffer, $\mathrm{pH} 7 \cdot 6$, containing $0.03 \mathrm{M}$-nicotinamide and $0.004 \mathrm{M}-\mathrm{MgCl}_{2}$ (Bucher \& $\mathrm{Mc}$ Garrahan, 1956) was used. Unbroken cells, nuclei and large cell debris were removed by centrifuging at $700 \mathrm{~g}$ for $15 \mathrm{~min}$.; the supernatant obtained is designated below as 'homogenate'. Mitochondria were removed from the homogenates by centrifuging at $10000 \mathrm{~g}$ for $25 \mathrm{~min}$.; the supernatant, containing soluble proteins and microsomes, is termed $\mathrm{S}_{10}$.

Incubations. All incubations were made at $37^{\circ}$ for $2-3 \mathrm{hr}$. In some experiments squalene was added to the incubations; the squalene ( $20 \mathrm{mg}$.) was dissolved in $1 \mathrm{ml}$. of light petroleum (b.p. $40-60^{\circ}$ ) and added to the empty flasks. The solvent was removed by heating on the water bath under a current of $\mathrm{N}_{2}$; the enzyme preparations were added afterwards.

Coenzymes. Adenosine triphosphate (ATP) was the crystalline product of the Sigma Chemical Co., St Louis, Mo., U.S.A. Diphosphopyridine nucleotide (DPN), 95\% pure, was obtained from the Pabst Laboratories, Milwaukie, Wis., U.S.A. DPNH (about $64 \%$ of reduced coenzyme) and crystalline alcohol dehydrogenase were purchased from Boehringer und Soehne, Mannheim, Germany.

Isolation of squalene and of cholesterol, and degradation of squalene. The methods used have been described previously (Popják, 1954; Cornforth \& Popják, 1954). Since the results of the degradation of $\left[{ }^{14} \mathrm{C}\right]$ squalene may not be readily understood without reference to our previous work, a brief description of the main features of the procedure is included in the main text.

Assay of ${ }^{14} \mathrm{C}$. This was done with a thin mica-window Geiger-Müller counter as described previously (Popják, 1950). All counts were corrected to infinite thickness. Under our present counting conditions a sample which contains $1 \mu \mathrm{C}$ of ${ }^{14} \mathrm{C} / \mathrm{g}$. gives at infinite thickness 1250 counts $/ \mathrm{min} . / 2 \mathrm{~cm} .{ }^{2}$ area. Two batches of $\left[2-{ }^{14} \mathrm{C}\right] \mathrm{mevalonic}$ acid (assayed as the diphenylmethyl amide) were used: one with a specific activity of $0.048 \mu \mathrm{c} / \mu$ mole and another with an activity of $0.2 \mu \mathrm{c} / \mu$ mole. The number of micromoles of lactone used in biosynthesis was calculated from the specific activities of squalene and of cholesterol and from the weight of these products isolated.

\section{RESULTS}

Table 1 shows that liver homogenates to which squalene had been added at the start of the incubations converted $\left[2-{ }^{14} \mathrm{C}\right]$ mevalonic acid into squalene with a high degree of efficiency: out of $10 \mu$ moles of the DL-acid over $3 \mu$ moles appeared in squalene. In comparison only minute amounts of acetate were used for the synthesis of either squalene or of cholesterol. When squalene carrier was added to the homogenates not at the start of the incubations but at the end, most of the radioactivity appeared in the digitonin-precipitable sterols rather than in squalene (Table 2). However, the sum of the micromoles of mevalonic acid used for squalene plus sterol synthesis was the same whether squalene carrier was added to the homogenates or not.

The full homogenate was not required for either squalene or sterol synthesis: the mitochondria could be removed by centrifuging without impairing materially the synthetic activity of the preparations. Table 3 shows that in the $S_{10}$ preparations only squalene was synthesized from mevalonic acid under anaerobic conditions. Under aerobic conditions most of the radioactivity

Table 1. Synthesis of squalene and of sterol from $\left[2{ }^{14} \mathrm{C}\right]$ mevalonic acid $(M V A)$ and from [carboxy$\left.{ }^{14} \mathrm{C}\right]$ acetate by liver homogenates

Each flask contained: $13 \mathrm{ml}$. of homogenate, $10 \mu$ moles of $\left[2 .{ }^{14} \mathrm{C}\right] \mathrm{MVA}$ or $\left[1 .{ }^{14} \mathrm{C}\right]$ acetate, $6 \mu$ moles of DPN and $20 \mathrm{mg}$. of squalene. Incubation was at $37^{\circ}$ for $2 \mathrm{hr}$.

\begin{tabular}{lccl} 
& \multicolumn{3}{c}{$\begin{array}{c}\mu \text { moles of substrate } \\
\text { converted into }\end{array}$} \\
Substrate & $\overbrace{\text { Squalene }}$ & Sterol & Gas phase \\
MVA & $3 \cdot 120$ & $0 \cdot 108$ & Air \\
Acetate & 0.016 & 0.082 & Air \\
MVA & $\mathbf{3 . 2 3}$ & 0.025 & Nitrogen \\
Acetate & $\mathbf{0 . 0 8 5}$ & 0.009 & Nitrogen
\end{tabular}

Table 2. Synthesis of squalene and of sterol from $\left[2 .{ }^{14} \mathrm{C}\right]$ mevalonic acid by liver homogenate

The flasks contained: $8 \mathrm{ml}$. of homogenate, $10 \mu$ moles of [2-14 C]MVA and $6 \mu$ moles of DPN. Squalene $(20 \mathrm{mg}$.) was added to one of the flasks. Incubation was at $37^{\circ}$ for $2 \mathrm{hr}$. 45 min.; gas phase air.

$\begin{array}{lcc}\text { Addition } & \text { Squalene } & \text { Sterol } \\ \text { Squalene } & \mathbf{1 . 1 6} & \mathbf{0 . 8 4} \\ \text { None } & \mathbf{0 . 2 8} & \mathbf{1 . 7 0}\end{array}$


appeared in the sterols. Here too the presence of squalene in the reaction mixture from the start of the incubation had the effect of increasing the amount of ${ }^{14} \mathrm{C}$ appearing in squalene and decreasing the amount in the sterol, but occasionally depressed the overall utilization of mevalonic acid (cf. Tables 2 and 3). When the diphosphopyridine nucleotide added to the incubation mixture was kept reduced with alcohol dehydrogenase and ethanol, there was more than a twofold increase in the amount of mevalonic acid incorporated into squalene.

Next we carried out several large-scale incubations of the type shown in Table 1 in order to prepare $\left[{ }^{14} \mathrm{C}\right]$ squalene from $\left[2-{ }^{14} \mathrm{C}\right]$ mevalonic acid in amounts sufficient for chemical degradations. In all, $131 \mathrm{mg}$. of $\left[{ }^{14} \mathrm{C}\right]$ squalene was isolated from eight experiments; this material, after the initial separations from cholesterol by chromatography on alumina, was rechromatographed twice with a few milligrams of inactive cholesterol. There was no change in specific activity. The squalene isolated from the incubations was diluted with inactive material to $1 \mathrm{~g}$.; one-half of this was used for degradation by ozonolysis, which cleaves squalene into acetone, laevulinic and succinic acids (cf. scheme 2, Cornforth \& Popják, 1954). Since squalene is an isoprenoid polymer, from the biosynthetic point of view it contains only five types of carbon atoms, which may be denoted, according to Klyne's (1954) notation, by the letters $w, w^{\prime}, x$, $y$ and $z$ (cf. formula VIII)

$$
\left(\begin{array}{c}
w^{\prime} \\
1 \\
1 \\
w-x=y-z
\end{array}\right)_{3}-\left(\begin{array}{c}
w^{\prime} \\
1 \\
z-y=x-w
\end{array}\right)_{3}
$$

The acetone is derived from the terminal isopropylidene groups and contains carbon atoms

Table 3. Synthesis of squalene and of sterol from $\left[2-{ }^{14} \mathrm{C}\right]$ mevalonic acid by $S_{10}$ preparation*

Each flask contained: enzyme $\left(\mathrm{S}_{10}\right) \mathbf{2 \cdot 5} \mathrm{ml}$; $5 \mu$ moles of ATP; $3 \mu$ moles of DPN; $0 \cdot 5 \mu$ mole of $\left[2-{ }^{14} \mathrm{C}\right] \mathrm{MVA}$. Addition of squalene (10 mg.) and gas phase as indicated. Incubations were in Warburg flasks at $37^{\circ}$ for $2 \mathrm{hr}$. In the anaerobic incubations the MVA was tipped in from the side arms 10 min. after flushing out the flasks with $\mathrm{N}_{2}$ and closing of the manometer taps.

\begin{tabular}{lll} 
Addition and & \multicolumn{2}{c}{$\boldsymbol{\mu \text { moles of MVA found in }}$} \\
\cline { 2 - 3 } gas phase & Squalene & Sterol \\
Squalene; air & 0.016 & 0.097 \\
Squalene; air & $0.039 \dagger$ & $0.077 \dagger$ \\
No addition; air & 0.003 & 0.141 \\
No addition; air & 0.004 & 0.135 \\
No addition; $\mathrm{N}_{2}$ & $\mathbf{0 . 1 4 3}$ & 0.000 \\
No addition; $\mathrm{N}_{2}$ & 0.132 & 0.000
\end{tabular}

* $S_{10}$ represents homogenate less mitochondria.

$\dagger$ In this flask the DPN was kept reduced with $0.6 \mathrm{mg}$. of alcohol dehydrogenase and $10 \mu$ moles of ethanol. $w-x-w^{\prime}$. The acetone was further degraded by treatment with sodium hypoiodite into iodoform (carbons $w$ and $w^{\prime}$ ) and acetic acid (derived equally from $w+x$ and $\left.w^{\prime}+x\right)$. The laevulinic acid molecules obtained from either side of the squalene contain the five carbon atoms of the isoprenoid units in the order $w^{\prime}-x-w-z-y, y$ being the carboxyl group and $x$ the carbonyl-carbon atom. It follows that the carbon-by-carbon degradation of laevulinic acid alone will indicate the distribution of the label in the squalene molecule. This is fortunate because the succinic acid, which might be expected to contain only the four central carbon atoms of squalene $(-y-z-z-y-)$, is apparently also derived to a small extent from carbon atoms $-y-z-w-x-$, and hence is not entirely suitable for our purpose.

The laevulinic acid was further split into acetic [containing the carboxyl (C-1) and C-2 of laevulinic acid] and propionic acids (C-3, -4 and -5 of laevulinic acid) as described previously (Cornforth \& Popják, 1954).

The results are shown in Table 4, in which the first column of figures gives the specific activity of the total carbon of the squalene and that of its fragments; the second column shows the molar specific activities, which were obtained by multiplying the figures of the first column by the number of the carbon atoms contained in the particular fragment. The molar specific activity of the squalene is given as a multiple of 6 since it consists of 6 isoprenoid units.

The sum of the molar specific activities of the two fragments obtained from the acetone was equal to one-sixth of the molar specific activity of the squalene. Since the specific activity of the acetic acid [containing equally carbon atoms $(w+x)$ and $\left.\left(w^{\prime}+x\right)\right]$ was one-half of the specific activity of the methyl carbon atoms of acetone ( $w$ and $\left.w^{\prime}\right)$, it is evident that carbon atom $x$ contains no ${ }^{14} \mathrm{C}$ and that the radioactivity of the acetone is either distributed between $w$ and $w^{\prime}$ or is contained only in one of these carbon atoms.

The laevulinic acid, which was assayed both as the 2:4-dinitrophenylhydrazone and as 4-aminopentanoic acid, had a molar specific activity onesixth of that of squalene. All the radioactivity of the laevulinic acid was confined to one carbon atom, $w$, which is C-3 of this acid and appeared in the process of degradation as the carboxyl-carbon atom of propionic acid.

\section{DISCUSSION}

Mevalonic acid, as shown by our results, is a precursor not only of cholesterol as shown by Tavormina et al. (1956) but also of squalene. The fact that under anaerobic conditions liver preparations synthesize squalene from mevalonic acid and 
Table 4. Distribution of ${ }^{14} \mathrm{C}$ in squalene biosynthesized from $\left[2 \cdot{ }^{14} \mathrm{C}\right]$ mevalonic acid

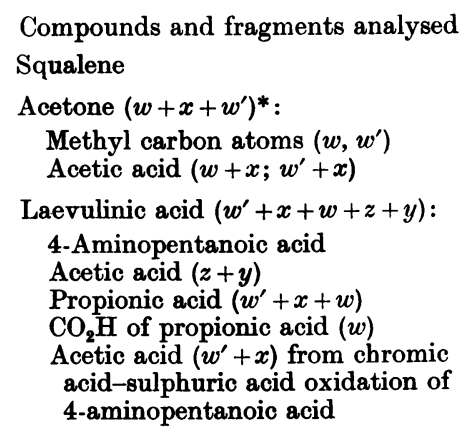

Specific activity of total carbon, counts/min. at infinite thickness \pm standard error $788 \pm 39$

Molar specific activity $3940 \times 6$

$1967 \pm 98$

$1040 \pm 52$

1967

2080

\begin{tabular}{|c|c|}
\hline $777 \pm 39$ & 3890 \\
\hline $\begin{array}{c}0 \\
1325+66\end{array}$ & $\begin{array}{r}0 \\
3975\end{array}$ \\
\hline $\begin{array}{c}3880 \pm 194 \\
0\end{array}$ & $\begin{array}{r}3880 \\
0\end{array}$ \\
\hline
\end{tabular}

* The letters in parentheses indicate, according to Klyne (1954), the carbon atoms of isoprenoid units.

aerobically mostly sterol, just as happens when acetate is used as a precursor (Bucher \& McGarrahan, 1956), adds further weight to the view (see Bloch, 1952) that squalene is an intermediate in the biosynthesis of sterols.

The results of the degradation of squalene biosynthesized from $\left[2{ }^{14} \mathrm{C}\right]$ mevalonic acid showed that there were only six labelled positions in the squalene, one in each of the two terminal isopropyl groups and four within the carbon chain of the hydrocarbon corresponding to carbon atom $w$ of the isoprenoid units. Although by the degradation of acetone we cannot distinguish between carbon atoms $w$ and $w^{\prime}$, the analysis of the carbon atoms of the laevulinic acid indicated the presence of ${ }^{14} \mathrm{C}$ in only carbon atom $w$; hence we infer that even in the terminal isopropyl groups only one atom is labelled. The mevalonic acid therefore must have given rise to an isoprenoid unit, which without further degradation underwent polymerization to squalene. The results further showed that C-2 and the 3-methyl carbon atom of mevalonic acid remained distinct during the biosynthetic process. That the two terminal 'methyl' groups of the isoprenoid units undergoing condensation to squalene have remained asymmetrically labelled is open to two interpretations. First the possibility must be considered that mevalonic acid itself or another $\mathrm{C}_{6}$ compound derived from it is the condensing unit, C-5 of one unit being linked to C-2 of another unit; this leads to a hypothetical product containing not only branched methyl but also branched carboxyl groups, the latter being removed afterwards (cf. IX). The second possibility is that C-1 of mevalonic acid is lost before the condensation, leaving a compound with an isopentane (or isopentene) carbon skeleton. Such a compound might even have two apparently indistinguishable methyl<smiles>CCC=C(C)C(CC=C(C)CC(=O)O)C(=O)O</smiles>

(IX)

groups and yet be treated by enzymes in an asymmetric manner. Apart from the type of enzyme reactions that maintain an asymmetric labelling in citric acid (Ogston, 1948) there are other possibilities of an isoprenoid unit formed from mevalonic acid remaining asymmetric in respect of its two 'methyl' carbon atoms. These questions might be resolved by isolation of the immediate successors of mevalonic acid in the sequence leading to squalene. From enzyme incubations at least one substance derived from mevalonic acid has been isolated which on paper chromatograms appears to be far more polar than mevalonic acid (G. Popják \& A. de Waard, unpublished work).

Since this work was completed and reported briefly (Cornforth et al. 1957) Dituri, Gurin \& Rabinowitz (1957) published results on the degradation of squalene biosynthesized from [2.14 $\mathrm{C}]$ mevalonic acid which are essentially identical with ours. These authors, however, favour the view that mevalonic acid or another $\mathrm{C}_{6}$ compound derived from it is the condensing unit rather than a $\mathrm{C}_{5}$ compound. Amdur, Rilling \& Bloch (1957) have also reported the synthesis of squalene from $\left[2{ }^{14} \mathrm{C}: 5-{ }^{3} \mathrm{H}\right]$ mevalonic acid by a particle-free extract of baker's yeast. The ${ }^{14} \mathrm{C} /{ }^{3} \mathrm{H}$ ratio in the squalene synthesized was the same as in the mevalonic acid. By this observation Amdur et al. (1957) excluded the possibility that C-5 of meva- 
lonic acid is oxidized to carboxyl before condensation. They also suggest that the condensing unit in the synthesis of squalene is mevalonic acid itself or 'a derivative of the same oxidation level'.

We have considered various possible transformations that mevalonic acid might undergo before the formation of squalene. In particular we envisaged that it may be first dehydrated either to the $\alpha \beta$ - or $\beta \gamma$-unsaturated compound (to 5-hydroxy-3-methylpent-2-enoic or to 5-hydroxy-3-methylpent-3-enoic acids or lactones). The compounds (II)-(VII), whose formulae were shown in Scheme 1, were synthesized and tested with the liver preparations $\left(\mathrm{S}_{10}\right)$ as possible precursors of cholesterol. Although the $\alpha \beta$-unsaturated lactone (unlabelled) depressed the incorporation of ${ }^{14} \mathrm{C}$ from $\left[2{ }^{14} \mathrm{C}\right]$ mevalonic acid into cholesterol by about $70 \%$, the labelled compound, either in the lactone or free acid form, gave no $\left[{ }^{14} \mathrm{C}\right]$ cholesterol. No incorporation of label into cholesterol from any of the other compounds shown in Scheme 1 could be demonstrated either. These negative results can mean either that none of these substances is on the pathway from mevalonic acid to squalene and cholesterol or that an enzyme required to make the activated form of such intermediate(s) is lacking. The products (II)-(VII) are all derived from mevalonic acid by loss of one or two molecules of water; the only notable absentee among these anhydro compounds is trans-5hydroxy-3-methylpent-2-enoic acid.

One further experiment may be mentioned briefly. The possibility occurred to us that mevalonic acid after dehydration and decarboxylation could give rise to isoprene itself which could readily polymerize by electron shifts induced by the attack of a cation. We have carried out an experiment in which an $S_{10}$ liver preparation was incubated in a sealed system with $\left[2{ }^{14} \mathrm{C}\right]$ mevalonic acid and unlabelled isoprene. At the end of a $2 \mathrm{hr}$. incubation the isoprene was trapped under reduced pressure into a receiver cooled with liquid air and containing a saturated solution of sulphur dioxide. The isoprene-sulphur dioxide polymer was isolated, but it contained no traces of radioactivity. On the other hand, the isoprene depressed the incorporations of ${ }^{14} \mathrm{C}$ from mevalonic acid into cholesterol to one-half of the control value. In the control experiment $\mathbf{1 . 6} \mu$ moles of the acid were converted into sterol(s) by $10 \mathrm{ml}$. of $\mathrm{S}_{10}$; in the presence of isoprene $(50 \mathrm{mg}$. were added, most of which of course existed in the vapour phase at $37^{\circ}$ ) only $0.83 \mu$ mole of the acid was utilized. We do not think it justifiable to conclude that the isoprene had 'diluted' the radioactivity derived from mevalonic acid; it is more likely that it was toxic to the preparation.

All experimental evidence indicates that the cyclization of squalene to sterol (lanosterol) proceeds according to the general scheme put forward by Woodward \& Bloch (1953). We may thus predict the positions of labelled carbons in lanosterol and cholesterol derived from $\left[2-{ }^{14} \mathrm{C}\right] \mathrm{meva}$ lonic acid. This is shown in Scheme 2. [Since this paper was submitted for publication Isler, Rüegg, Würsch, Gey \& Pletscher (1957) reported the partial degradation of $\left[{ }^{14} \mathrm{C}\right]$ cholesterol biosynthesized from $\left[2{ }^{14} \mathrm{C}\right]$ mevalonic acid. They found that C-7, C-22 and either C-26 or C-27 of the sterol were labelled. The results were consistent with the assumption that the $\left[{ }^{14} \mathrm{C}\right]$ cholesterol contained

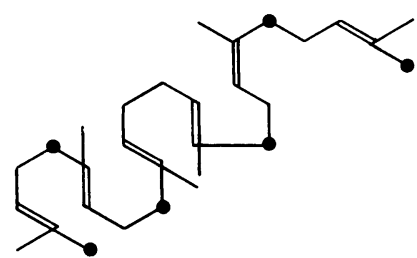

Squalene

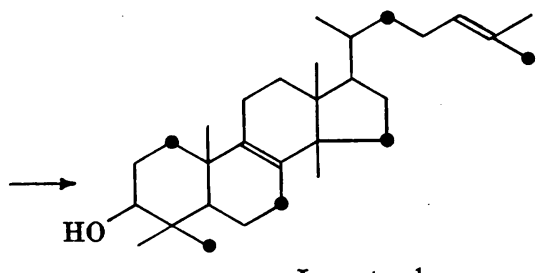

Lanostarol

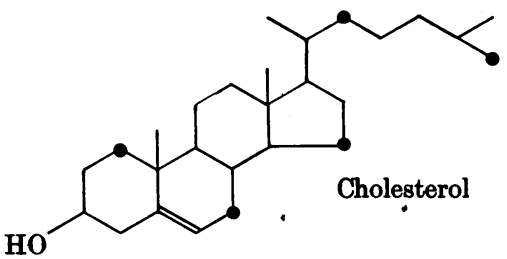

Scheme 2. Predicted labelling of sterol formed by cyclization of squalene biosynthesized from [2-14C]mevalonic acid. The black circles indicate the labelled positions in squalene and in sterols. 
only five labelled positions and are thus in complete agreement with our prediction.] If it is assumed, as Tavormina et al. (1956) suggested, that only one of the optical enantiomorphs of the synthetic DL-mevalonic acid is used in sterol synthesis we may calculate that the maximum utilization of the $\mathrm{DL}-\left[2-{ }^{14} \mathrm{C}\right]$ mevalonic acid for cholesterol synthesis should not exceed $50 \times 5 / 6=$ $41.7 \%$. In the experiments of Tavormina et al. (1956) a maximum of $43 \%$ of the DL-acid was converted into cholesterol. In numerous experiments, not reported here, with various liver preparations we have never observed a conversion greater than $42 \%$. Gould \& Popják (1957) reported that after administration of $\mathrm{DL}-\left[2-{ }^{14} \mathrm{C}\right]$ mevalonic acid to mice $40 \%$ of the radioactive dose could be recovered in body cholesterol, $10 \%$ in expired carbon dioxide and $50 \%$ in the urine. Since in the conversion of lanosterol into cholesterol the three methyl carbon atoms of the former, from positions $4: 4^{\prime}$ and 14, are removed as carbon dioxide (Gautschi \& Bloch, 1957), on complete utilization of one enantiomorph of $\left[2-{ }^{14} \mathrm{C}\right]$ mevalonic acid for cholesterol synthesis $8.3 \%$ of the ${ }^{14} \mathrm{C}$ must appear as dioxide.

\section{EXPERIMENTAL}

\section{Preparation of 3-hydroxy-3-methylpentano-5-lactone (mevalonic lactone)}

3-Oxobutyl acetate. 3-Oxobutanol was prepared by the method of White \& Haward (1943) and acetylated according to Buchman \& Sargent (1945) with acetic anhydride and concentrated sulphuric acid. It was inadvisable to increase the scale of the acetylation beyond $10 \mathrm{~g}$. of oxobutanol, but the products of several runs could be combined for distillation. In a typical experiment $30 \mathrm{~g}$. of oxobutanol was acetylated in three batches of $10 \mathrm{~g}$.; after $45 \mathrm{~min}$. a little anhydrous sodium acetate was added and the mixture distilled from a fractionating Claisen flask, giving 35 g., b.p. $78-84^{\circ} / 15 \mathrm{~mm}$. This was heated at $35-40^{\circ}$ at $0.2 \mathrm{~mm}$. for $1.5 \mathrm{hr}$. to remove acetic anhydride, then distilled, the first few millilitres of distillate being rejected until the distilling liquid gave no immediate strong acid reaction with moist litmus paper; yield 29.6 g., b.p. 36$38^{\circ} / 0 \cdot 2 \mathrm{~mm}$. On being kept for some time at room temperature oxobutyl acetate develops an acid reaction from the liberation of acetic acid; this does not occur at $4^{\circ}$.

Methyl 3-hydroxy-3-methyl-5-acetoxypentanoate. 3-0xobutyl acetate $(3.0 \mathrm{~g}$.$) and methyl bromoacetate (3.5 \mathrm{~g}$. were dissolved in dry ether ( $15 \mathrm{ml}$.$) and added to zinc$ filings (3.0 g.; 2 equiv., activated by washing with $2 \%$ hydrochloric acid, ethanol, acetone and dry ether and heating in vacuo with a crystal of iodine). The mixture was stirred and refluxed for $4 \mathrm{hr}$., during which time a gummy complex separated. (The reaction usually becomes exothermic for a time after a period varying from $20 \mathrm{~min}$. to $1.5 \mathrm{hr}$.) After cooling in ice-water the complex was decomposed with acetic acid $(1.3 \mathrm{ml}$.$) in water (10 \mathrm{ml}$.) with vigorous stirring. The aqueous layer was saturated with ammonium chloride and extracted four times with ether. The ethereal solution was washed with a small volume of saturated sodium bicarbonate solution, and the bicarbonate washing was saturated with sodium chloride and extracted once with ether. The ethereal solution was dried over anhydrous magnesium sulphate and evaporated, and the residue was distilled, giving $2.9 \mathrm{~g}$. (62\%) of methyl 3hydroxy-3-methyl-5-acetoxypentanoate, b.p. $80-82^{\circ} / 0 \cdot 1 \mathrm{~mm}$. (Found: C, 52.8; H, 7.6. $\mathrm{C}_{9} \mathrm{H}_{16} \mathrm{O}_{5}$ requires $\mathrm{C}, 52.9 ; \mathrm{H}$, $7 \cdot 8 \%$ ).

3-Hydroxy-3-methylpentano-5-lactone (I). Methyl 5acetoxy-3-hydroxy-3-methylpentanoate $(2.9 \mathrm{~g}$.) was allowed to stand at room temperature for $40 \mathrm{hr}$. with an excess of methanolic $\mathrm{N}$-potassium hydroxide solution (65 ml.); an equivalent amount of hydrogen chloride in methanol was added, the precipitated potassium chloride filtered after chilling and the filtrate evaporated. The residue was extracted with chloroform, and the solution was filtered, evaporated and distilled. The first distillation gave 1.95 g., b.p. $115^{\circ} / 0 \cdot 1 \mathrm{~mm}$.; redistillation gave a small fore-run and $1 \cdot 6 \mathrm{~g}$. (86\%) of 3-hydroxy-3-methylpentano5-lactone, b.p. $110^{\circ} / 0 \cdot 1 \mathrm{~mm}$. (Found: C, 55.5; H, 7.8. Calc. for $\mathrm{C}_{6} \mathrm{H}_{10} \mathrm{O}_{3}: \mathrm{C}, 55 \cdot 9 ; \mathrm{H}, 7 \cdot 7 \%$ ).

A paper chromatogram of the hydroxamate, developed with butanol-acetic acid-water $(4: 1: 5$, by vol.) and sprayed with ferric chloride solution gave a single spot with an $R_{F}$ of 0.57 . If an old, instead of a fresh, solvent system is used in chromatography, the hydroxamate moves more slowly $\left(R_{F} 0 \cdot 42-0 \cdot 45\right)$.

The diphenylmethylamide was prepared by refluxing with a slight excess of diphenylmethylamine in benzene for $1 \mathrm{hr}$. The benzene was evaporated and the residue was rubbed with dilute phosphoric acid, collected, washed with water until acid free, dried and recrystallized from benzene. It had m.p. 97-98 ${ }^{\circ}$. [Wolf et al. (1956) gave m.p. 93-95 ${ }^{\circ}$ for the diphenylmethylamide of DL-mevalonic acid and Eggerer, Lynen, Rauenbusch \& Kessel (1957) gave m.p. 96-97.$]$

The (-)menthoxyacetate of the diphenylmethylamide was prepared by treatment with ( - )menthoxyacetyl chloride in pyridine. It crystallized in colourless prisms from cyclohexane or dibutyl ether. Repeated recrystallization raised the m.p. to $86-88^{\circ}$, but no resolution was effected (Found: $\mathrm{C}, 72.9 ; \mathrm{H}, 8.2 . \mathrm{C}_{31} \mathrm{H}_{43} \mathrm{O}_{5} \mathrm{~N}$ requires $\mathrm{C}, 73.1 ; \mathrm{H}$, 8.5).

3-Methylpent-2-eno-5-lactone (II). 3-Hydroxy-3-methylpentano-5-lactone $(2 \cdot 2 \mathrm{~g}$.) was heated in a distilling flask with fused potassium hydrogen sulphate $(4 \mathrm{~g}$.) at $14 \mathrm{~mm}$. Dehydration commenced at $80^{\circ}$ and the 3-methylpent-2eno-5-lactone distilled at $115-120^{\circ} / 14 \mathrm{~mm}$. (1.83 g.); redistillation gave $1.71 \mathrm{~g}$. $(91 \%)$, b.p. $118-120^{\circ} / 14 \mathrm{~mm}$., $n_{\mathrm{D}}^{21} 1 \cdot 4840$ (Found: $\mathrm{C}, 64 \cdot 4 ; \mathrm{H}, 7 \cdot 0 . \mathrm{C}_{6} \mathrm{H}_{8} \mathrm{O}_{2}$ requires $\mathrm{C}$, $64.3 ; \mathrm{H}, 7.1 \%$ ). That the new lactone formed was predominantly, if not entirely, $\alpha \beta$-unsaturated was shown by the facts that it could be titrated to only a very small extent with $0 \cdot 1 \mathrm{~N}-\mathrm{NaOH}$ even on warming, that it did not react with diphenylmethylamine in boiling benzene and that its ultraviolet absorption (end absorption at $2140 \AA$, $\epsilon 8000)$ corresponds with that of hex-2-eno-5-lactone (parasorbic acid) (Haynes \& Jones, 1946). The unsaturated lactone polymerized slowly when kept at room temperature.

cis-5-Hydroxy-3-methylpent-2-enoic acid (III). 3-Methylpent-2-eno-5-lactone $(500 \mathrm{mg}$.) was heated on the steam bath for $15 \mathrm{~min}$. with $5 \mathrm{ml}$. of $\mathrm{N}$-sodium hydroxide and 
cooled and $2 \mathrm{~N}$-hydrochloric acid $(2.5 \mathrm{ml}$.) added. The solution was saturated with ammonium chloride and extracted five times with ether. The ethereal solution was dried and evaporated in vacuo and the residue recrystallized twice from benzene; cis-5-hydroxy-3-methylpent-2-enoic acid was thus obtained in colourless prisms (244 mg.), m.p. $72-73^{\circ}$ (Found: $\mathrm{C}, 55 \cdot 2 ; \mathrm{H}, 7 \cdot 6 ; \mathrm{C}_{6} \mathrm{H}_{10} \mathrm{O}_{3}$ requires $\mathrm{C}, 55.4$; H, $7 \cdot 7 \%$ ).

The S-benzylthiuronium salt was prepared by addition of an ethanolic solution of $S$-benzylthiuronium chloride to a neutral solution of the sodium salt and concentration of the solution in vacuo. It crystallized, from ethyl acetate containing a little ethanol, in colourless needles, m.p. $140^{\circ}$ (Found: $\mathrm{N}, 9 \cdot 6 . \mathrm{C}_{14} \mathrm{H}_{20} \mathrm{O}_{3} \mathrm{~N}_{2} \mathrm{~S}$ requires $\mathrm{N}, 9 \cdot 5 \%$ ).

The acid liquefied slowly on keeping; titration showed that the liquid was largely lactone. Esterification with diazomethane in ether gave methyl cis-5-hydroxy-3-methylpent-3-enoate, b.p. $114^{\circ} / 15 \mathrm{~mm}$. (Found: C, 58.3; H, 8.6. $\mathrm{C}_{7} \mathrm{H}_{12} \mathrm{O}_{3}$ requires $\left.\mathrm{C}, 58 \cdot 3 ; \mathrm{H}, 8 \cdot 3 \%\right), n_{\mathrm{D}}^{20} 1 \cdot 4729$, ultraviolet absorption, $\lambda_{\max } 2200 \AA$ ( $\left.\epsilon 12000\right)$.

cis-3-Methylpenta-2:4-dienoic acid (IV). This was prepared from 3-methylpent-2-eno-5-lactone by a modification of the method of Eisner, Elvidge \& Linstead (1953), who converted hex-2-eno-5-lactone into cis-trans-sorbic acid by means of sodium methoxide in methanol. Potassium (90 mg.) was dissolved in tert.-butanol (2.5 ml.), the solution cooled and diluted with dry ether $(1 \mathrm{ml}$.). 3-Methylpent-2eno-5-lactone $(260 \mathrm{mg}$.) in dry ether (1 ml.) was added with cooling in ice. The potassium salt of cis-3-methylpenta-2:4dienoic acid was precipitated immediately; it was collected (313 mg.) and dissolved in a small volume of water and the solution acidified to Congo red with dilute sulphuric acid. The precipitated acid was collected, washed with icewater and dried (173 mg.; yield 66\%, m.p. 65-67 $)$. The acid recrystallized from water or light petroleum (b.p. 40$60^{\circ}$ ) in colourless needles or prisms, m.p. 66-67 ${ }^{\circ}$ (Found: $\mathrm{C}, 64 \cdot 4$; $\mathrm{H}, 7 \cdot 3$. $\mathrm{C}_{6} \mathrm{H}_{8} \mathrm{O}_{2}$ requires $\mathrm{C}, 64 \cdot 3 ; \mathrm{H}, 7 \cdot 1 \%$ ). Ultraviolet absorption, $\lambda_{\max }$. $2500 \AA(\epsilon 17000)$. It polymerized slowly at room temperature.

The S-benzylthiuronium salt crystallized from ethanolethyl acetate in colourless prisms, m.p. 146-147 ${ }^{\circ}$ (Found: C, $60.0 ; \mathrm{H}, 6.4 ; \mathrm{N}, 9.9 \% . \mathrm{C}_{14} \mathrm{H}_{18} \mathrm{O}_{2} \mathrm{~N}_{2} \mathrm{~S}$ requires $\mathrm{C}, 60.4$; $\mathrm{H}, 6 \cdot 5 ; \mathrm{N}, 10 \%$ ).

3-Hydroxy-3-methylpent-4-enoic acid (V). Methyl vinyl ketone (18.6 g.) and methyl bromoacetate (38 g.; slight deficiency) were dissolved in dry benzene $(100 \mathrm{ml}$.) and $30 \mathrm{ml}$. of the mixture was added to activated zinc filings $(20 \mathrm{~g}$.) in dry benzene $(100 \mathrm{ml}$.). The mixture was refluxed and stirred until reaction set in (about $1 \mathrm{hr}$.); the remainder of the solution was then added dropwise and refluxing continued for $1 \mathrm{hr}$. after the addition. The mixture was cooled and decomposed with an ice-cold solution of acetic acid $(20 \mathrm{ml}$.$) in water (180 \mathrm{ml}$.) with stirring. The aqueous layer was saturated with ammonium chloride and extracted several times with ether. The combined benzene-ether solution was washed free of acid with sodium bicarbonate solution; the washings were saturated with sodium chloride and re-extracted with ether. After evaporation of the solvents, distillation of the residue gave methyl 3-hydroxy-3methylpent-4-enoate $(17.2 \mathrm{~g}$; $48 \%$, calculated on methyl bromoacetate), b.p. $69-70^{\circ} / 15 \mathrm{~mm} ., n_{\mathrm{D}}^{20} \mathrm{l} \cdot 4391$ (Found: $\mathrm{C}$, $58 \cdot 2 ; \mathrm{H}, 8 \cdot 3 . \mathrm{C}_{7} \mathrm{H}_{12} \mathrm{O}_{3}$ requires $\mathrm{C}, 58 \cdot 3 ; \mathrm{H}, 8 \cdot 3 \%$ ). The ester is soluble in water. Heilbron, Jones, Julia \& Weedon (1949) prepared the corresponding ethyl ester in $34 \%$ yield by the Reformatsky reaction; their lower yield was probably due to loss during working up because of the solubility of the substance in water.

The ester $(2.8 \mathrm{~g}$.) was hydrolysed with methanolic $\mathrm{N}$ potassium hydroxide $(38 \mathrm{ml}$.) for $48 \mathrm{hr}$.; $38 \mathrm{~m}$-equiv. of methanolic hydrogen chloride was added, the solution was filtered and evaporated and the residue distilled. 3Hydroxy-3-methylpent-4-enoic acid $\left(1.9 \mathrm{~g}\right.$.) distilled at $86^{\circ}$ / $0.05 \mathrm{~mm}$. (Found: $\mathrm{C}, 55.3 ; \mathrm{H}, 8 \cdot 1 . \mathrm{C}_{6} \mathrm{H}_{10} \mathrm{O}_{3}$ requires $\mathrm{C}$, $55 \cdot 4 ; \mathrm{H}, 7 \cdot 7 \%$ ). The acid showed no ultraviolet absorption.

The S-p-nitrobenzylthiuronium salt crystallized from ethanol in faintly yellow prisms, m.p. $139^{\circ}$ (Found: $\mathrm{C}, 49 \cdot 2$; $\mathrm{H}, 5 \cdot 7 . \mathrm{C}_{14} \mathrm{H}_{19} \mathrm{O}_{5} \mathrm{~N}_{3} \mathrm{~S}$ requires $\mathrm{C}, 49 \cdot 3 ; \mathrm{H}, 5 \cdot 6 \%$ ).

Allylic rearrangement of methyl 3-hydroxy-3-methylpent-4enoate. After the failure of some attempts to rearrange methyl 3-hydroxy-3-methylpent-4-enoate directly with dilute sulphuric acid, the indirect method, frequently used in the terpene series, via the primary bromide and acetate (cf. Ruzicka \& Firmenich, 1939), was successfully applied.

Methyl 3-hydroxy-3-methylpent-4-enoate (9 g.) was dissolved in light petroleum (b.p. $\left.40-60^{\circ}\right)(18 \mathrm{ml}$.) containing pyridine $(1.5 \mathrm{ml}$.) and a solution of phosphorus tribromide $(2 \cdot 7 \mathrm{ml}$.) in light petroleum $(10 \mathrm{ml}$.) added dropwise during $30 \mathrm{~min}$. with stirring at $-7^{\circ}$. The mixture was stirred for $2 \mathrm{hr}$. longer, the temperature being allowed to rise gradually to $10^{\circ}$. Ice-water was then added and stirring continued for $15 \mathrm{~min}$. The petroleum layer was separated, washed with water and with dilute sodium bicarbonate solution, dried and evaporated in vacuo. The crude bromide $(11.8 \mathrm{~g}$.) was shaken with powdered anhydrous potassium acetate (36 g.) in dry acetone $(240 \mathrm{ml}$.) for several days. After filtration the acetone was evaporated and the residue was dissolved in ether, washed with sodium bicarbonate solution, dried, evaporated and distilled; it gave $3.3 \mathrm{~g}$., b.p. $56-60^{\circ} / 15 \mathrm{~mm}$., a small intermediate fraction, and 3.7 g., b.p. $58-60^{\circ} / 0.01 \mathrm{~mm}$. The fraction with the lower b.p. was methyl 3-methylpenta-2:4-dienoate (Found: C, $66 \cdot 7 ; \mathrm{H}, 8 \cdot 0$. $\mathrm{C}_{7} \mathrm{H}_{10} \mathrm{O}_{2}$ requires $\mathrm{C}, 66 \cdot 7 ; \mathrm{H}, 7 \cdot 9 \%$. Ultraviolet absorption, $\lambda_{\max .} 2500 \AA$ ( $\left.\left.\epsilon 20000\right) ; n_{D}^{21} 1 \cdot 4902\right)$. Gasphase chromatography (kindly carried out by $\operatorname{Dr}$ A. T. James) showed this to be a mixture of approximately equal amounts of cis and trans esters. The fraction with the higher b.p. was methyl 5-acetoxy-3-methylpent-3-enoate (Found: C, 58.1; $\mathrm{H}, 7 \cdot 9 . \mathrm{C}_{9} \mathrm{H}_{14} \mathrm{O}_{4}$ requires $\mathrm{C}, 58 \cdot 1 ; \mathrm{H}$, $7 \cdot 5 \%$ ). Ultraviolet absorption, end absorption at $2150 \AA$ $(\epsilon 1300) ; n_{\mathrm{D}}^{21} 1.4530$.

3-Methylpenta-2:4-dienoic acid (cis-trans mixture) (VI). Methyl 3-methylpenta-2:4-dienoate $(1 \mathrm{~g}$.$) was hydrolysed$ with cold methanolic $\mathrm{N}$-potassium hydroxide $(16 \mathrm{ml}$.) for 5 days; after removal of the methanol, addition of water and acidification, the product was isolated by ether extraction. 3-Methylpenta-2:4-dienoic acid $(0.7 \mathrm{~g}$.) was obtained, b.p. $60^{\circ} / 0 \cdot 04 \mathrm{~mm}$. (Found: C, 63.5; H, 7.6. Calc. for $\mathrm{C}_{6} \mathrm{H}_{8} \mathrm{O}_{2} \mathrm{C}, 64.3 ; \mathrm{H}, 7 \cdot 1 \%$ ). Ultraviolet absorption, $\lambda_{\text {max. }} 2500 \AA$ ( $\left.\epsilon 17000\right)$. The acid crystallized on cooling to $0^{\circ}$.

The $S$-benzylthiuronium salt crystallized from aqueous $50 \%$ ethanol or from ethanol-ethyl acetate in colourless needles, m.p. 153-154 ${ }^{\circ}$, mixed m.p. with $S$-benzylthiuronium salt of the pure cis acid, 148-149 ${ }^{\circ}$. Heilbron et al. (1949) give m.p. $162^{\circ}$ for the $S$-benzylthiuronium salt of the dienoic acid obtained by rearrangement of the condensation product of ethoxyethynylmagnesium bromide with methyl vinyl ketone or by dehydration of the Reformatsky 
product from ethyl bromoacetate and methyl vinyl ketone followed by hydrolysis. Their acid had $\lambda_{\max .} 2490 \AA$ ( $\epsilon$ $20500)$.

cis- and trans-5-Hydroxy-3-methypent-3-enoic acids (VII). Methyl 5-acetoxy-3-methylpent-3-enoate (3.0 g.) was hydrolysed with $0 \cdot 1 \mathrm{~N}-\mathrm{NaOH}(470 \mathrm{ml}$.) for $24 \mathrm{hr}$., neutralized to phenol red, concentrated and acidified; the solution was saturated with ammonium chloride and extracted four times with ether. After drying and evaporation, the residue, consisting of a mixture of cis- and trans-5-hydroxy-3methylpent-3-enoic acids, was distilled. The cis acid lactonized, giving 3-methylpent-3-eno-5-lactone $(0.58 \mathrm{~g}$.), b.p. $62-66^{\circ} / 0.05 \mathrm{~mm}$., and the trans acid $(0.43 \mathrm{~g}$.) distilled at $126-130^{\circ} / 0 \cdot 05 \mathrm{~mm}$. Methanolic potassium hydroxide or aqueous alkali stronger than $0.1 \mathrm{~N}$ could not be used for the hydrolysis owing to the facile production of dienoic acid.

The lactone was purified by washing its ethereal solution with sodium bicarbonate solution, drying and redistilling; 0.33 g., b.p. $108-110^{\circ} / 14 \mathrm{~mm}$., was thus obtained (Found: $\mathrm{C}, 64 \cdot 0 ; \mathrm{H}, 7 \cdot 2 . \mathrm{C}_{6} \mathrm{H}_{8} \mathrm{O}_{2}$ requires $\mathrm{C}, 64 \cdot 3 ; \mathrm{H}, 7 \cdot 1 \%$ ). The lactone could be titrated slowly when hot with $0.1 \mathrm{~N}$ alkali. It polymerizes if kept at room temperature. The diphenylmethylamide, prepared as described for mevalonic lactone, crystallized from benzene in colourless prisms, m.p. $129-130^{\circ}$ (Found: $\mathrm{C}, 77 \cdot 4 ; \mathrm{H}, 7 \cdot 2 . \mathrm{C}_{19} \mathrm{H}_{21} \mathrm{O}_{2} \mathrm{~N}$ requires C, $77 \cdot 3 ; \mathrm{H}, 7 \cdot 1 \%$ ).

The trans-5-hydroxy-3-methylpent-3-enoic acid crystallized on keeping in the cold room. It was purified by lowtemperature $\left(-40^{\circ}\right)$ recrystallization from dry ether and thus obtained in colourless prisms, m.p. 50-52 ${ }^{\circ}$ (Found: $\mathrm{C}, 55 \cdot 6 ; \mathrm{H}, 8 \cdot 1 . \mathrm{C}_{6} \mathrm{H}_{10} \mathrm{O}_{3}$ requires $\mathrm{C}, 55 \cdot 4 ; \mathrm{H}, 7 \cdot 7 \%$ ). It did not give a crystalline $S$-benzylthiuronium salt.

Infrared spectra. For most of the products described the spectra showed bands in the expected regions, but those of 3-methylpent-2- and 3-methylpent-3-eno-5lactones showed a pronounced band in the hydroxyl region $\left(3200-3300 \mathrm{~cm}^{-1}\right)$. Treatment of the lactones with deuterium oxide and redistillation did not alter the infrared spectra; the bands at $3200-3300 \mathrm{~cm} .^{-1}$ are presumably overtones of C: O stretching absorption (Jones \& Sandorfy, 1956)

\section{Preparation of labelled compounds for biological experiments}

$\left[2-{ }^{14} \mathrm{C}\right]$ Mevalonic lactone. This was made on the scale described above by using methyl $\left[2{ }^{14} \mathrm{C}\right]$ bromoacetate prepared by esterifying $\left[2{ }^{14} \mathrm{C}\right]$ bromoacetic acid $(5.5 \mathrm{mc})$ (obtained from the Radiochemical Centre, Amersham, Bucks) with diazomethane and diluting to $3.5 \mathrm{~g}$. with unlabelled methyl bromoacetate. A previous less active specimen was made from $0.5 \mathrm{mc}$ diluted to $1.5 \mathrm{~g}$. These two specimens had specific activities of 0.2 and $0.048 \mu \mathrm{c} / \mu \mathrm{mole}$ respectively (assayed as the diphenylmethylamide).

3-Methyl-[2-14C]pent-2-eno-5-lactone. This was prepared, as described, from $\left[2-{ }^{14} \mathrm{C}\right] \mathrm{mevalonic}$ lactone $(0 \cdot 2 \mu \mathrm{c} / \mu \mathrm{mole}$; $30 \mathrm{mg}$.) diluted with unlabelled lactone $(90 \mathrm{mg}$.); $95 \mathrm{mg}$. of redistilled product was thus obtained.

cis-5-Hydroxy-3-methyl-[2-14 $\mathrm{C}]$ pent-2-enoic acid and cis3-methyl-[2-14 C]penta-2:4-dienoic acid. These were prepared as described above from $40 \mathrm{mg}$. samples of the unsaturated lactone.

3-Hydroxy-3-methyl-[2-14C]pent-4-enoic acid, 3-methyl$\left[2-{ }^{14} \mathrm{C}\right]$ penta-2:4-dienoic acid (cis- + trans-) and 5-hydroxy-3methyl- $\left[2-{ }^{14} \mathrm{C}\right]$ pent-3-enoic acid (cis- + trans-). The Reform- atsky reaction on methyl vinyl ketone was carried out, as described, with methyl bromoacetate $(1.5 \mathrm{~g}$. containing $0.5 \mathrm{mc}$ of methyl $\left[2-{ }^{14} \mathrm{C}\right]$ bromoacetate); $0.77 \mathrm{~g}$. (55\%) of methyl 3-hydroxy-3-methyl-[2-14C]pent-4-enoate was obtained. A portion (70 $\mathrm{mg}$.) of this ester was hydrolysed with methanolic potassium hydroxide, the methanol evaporated, the residue neutralized to phenol red with $0 \cdot 1 \mathrm{~N}-\mathrm{HCl}$ and the solution concentrated to $1 \mathrm{ml}$. The remainder of the ester ( $700 \mathrm{mg}$.) was converted as described into methyl 3-methyl-[2-14 C]penta-2:4-dienoate (199 mg.) and methyl 5-acetoxy-3-methyl-[2-14 C]pent-3-enoate (283 mg.). 3-Methyl-[2-14 C]penta-2:4-dienoic acid (cis- + trans-) was prepared by hydrolysis of the ester and isolated by distillation. A solution containing cis- and trans-5hydroxy-3-methyl-[2-14 C]pent-3-enoic acids was prepared by hydrolysis of the corresponding ester (59 mg.) with $0 \cdot 1 \mathrm{~N}-\mathrm{NaOH}$, neutralization and concentration to $1 \mathrm{ml}$.

\section{SUMMARY}

1. 3-Hydroxy-3-methylpentano-5-lactone (mevalonic lactone) and a number of other $\mathrm{C}_{6}$ compounds related to it have been synthesized and labelled with ${ }^{14} \mathrm{C}$ in position 2.

2. In liver homogenates $\left[2-{ }^{14} \mathrm{C}\right]$ mevalonic acid is an efficient precursor not only of sterols but also of squalene provided that the incubations are made anaerobically. Mitochondria are not required for the biosynthesis of either squalene or sterol.

3. $\left[{ }^{14} \mathrm{C}\right]$ Squalene biosynthesized from $\left[2-{ }^{14} \mathrm{C}\right]$ mevalonic acid was degraded chemically and was found to contain only six labelled positions in the chain of the molecule; the branched methylcarbon atoms of squalene were not labelled.

4. The results indicate that all carbon atoms in mevalonic acid retain their individuality during biosynthesis.

5. Six substances related to mevalonic acid (all being anhydro compounds of the acid) were also tested as possible intermediates in the biosynthesis of squalene and sterol, but all gave negative results.

We are grateful to Professor A. Wormall, F.R.S., for a generous supply of squalene.

\section{REFERENCES}

Adamson, L. F. \& Greenberg, D. M. (1957). Biochim. biophys. Acta, 23, 472.

Amdur, B. H., Rilling, H. \& Bloch, K. (1957). J. Amer. chem. Soc. 79, 2647.

Bachhawat, B. K., Robinson, W. G. \& Coon, M. J. (1954). J. Amer. chem. Soc. 76, 3098.

Bachhawat, B. K., Robinson, W. G. \& Coon, M. J. (1955). J. biol. Chem. 216, 727.

Bachhawat, B. K., Robinson, W. G. \& Coon, M. J. (1956). J. biol. Chem. 219, 539.

Bloch, K. (1952). Harvey Lect. 48, 68.

Bucher, N. L. R. \& McGarrahan, K. (1956). J. biol. Chem 222, 1. 
Buchman, E. R. \& Sargent, H. (1945). J. Amer. chem. Soc. 67, 401.

Coon, M. J. (1955). Fed. Proc. 14, 762.

Coon, M. J., Robinson, W. G. \& Bachhawat, B. K. (1955). In Amino Acid Metabolism, p. 431. Ed. by McElroy, W. D. \& Glass, B. Baltimore: Johns Hopkins Press.

Cornforth, J. W., Cornforth, R. H., Popják, G. \& Gore, I. Youhotsky (1957). Biochem. J. 66, 10P.

Cornforth, J. W., Gore, I. Youhotsky \& Popják, G. (1957). Biochem. J. 65, 94.

Cornforth, J. W., Hunter, G. D. \& Popják, G. (1953). Biochem. J. 54, 597.

Cornforth, J. W. \& Popják, G. (1954). Biochem. J. 58, 403.

Dituri, F., Gurin, S. \& Rabinowitz, J. L. (1957). J. Amer. chem. Soc. 79, 2650.

Eggerer, H., Lynen, F., Rauenbusch, E. \& Kessel, I. (1957). Liebigs Ann. 608, 71.

Eisner, U., Elvidge, J. A. \& Linstead, R. P. (1953). J. chem. Soc. p. 1372.

Gautschi, F. \& Bloch, K.(1957). J. Amer. chem. Soc. 79, 684 . Gould, R. G. \& Popják, G. (1957). Biochem. J. 66, 51 P.

Haynes, L. J. \& Jones, E. R. H. (1946). J.chem. Soc. p. 954. Heilbron, I., Jones, E. R. H., Julia, M. \& Weedon, B. C. L. (1949). J. chem. Soc. p. 1823.

Hoffman, C. H., Wagner, A. F., Wilson, A. N., Walton, E., Shunk, C. H., Wolf, D. E., Holly, F. W. \& Folkers, K. (1957). J. Amer. chem. Soc. 79, 2316.

Isler, O., Rüegg, R., Würsch, J., Gey, K. F. \& Pletscher, A. (1957). Helv. chim. acta, 40, 2369.
Jones, R. N. \& Sandorfy, C. (1956). In Technique of Organic Chemistry, vol. 9, p. 425. Ed. by A. Weissberger. New York: Interscience Publishers Inc.

Klyne, W. (1954). Chem. and Ind. p. 725.

Ogston, A. G. (1948). Nature, Lond., 162, 963.

Popják, G. (1950). Biochem. J. 46, 560.

Popják, G. (1954). Arch. Biochem. Biophys. 48, 102.

Rudney, H. (1954). .J. Amer. chem. Soc. 76, 2595.

Ruzicka, L. \& Firmenich, G. (1939). Helv. chim. acta, 22, 392.

Skeggs, M. R., Wright, L. D., Cresson, E. L., MacRae, G. D. E., Hoffman, C. H., Wolf, D. E. \& Folkers, K. (1956). J. Bact. 72, 519.

Tavormina, P. A. \& Gibbs, M. H. (1956). J. Amer. chem. Soc. 78, 6210.

Tavormina, P. A., Gibbs, M. H. \& Huff, J. W. (1956). J. Amer. chem. Soc. 78, 4498.

White, T. \& Haward, R. N. (1943). J. chem. Soc. p. 25.

Wolf, D. E., Hoffman, C. H., Aldrich, P. E., Skeggs, H. R., Wright, L. D. \& Folkers, K. (1956). J. Amer. chem. Soc. 78, 4499.

Wolf, D. E., Hoffman, C. H., Aldrich, P. E., Skeggs, H. R., Wright, L. D. \& Folkers, K. (1957). J. Amer. chem. Soc. 79, 1486.

Woodward, R. B. \& Bloch, K. (1953). J. Amer. chem. Soc. 75, 2023.

Würsch, J., Huang, R. L. \& Bloch, K. (1952). J. biol. Chem. $185,439$.

\title{
Studies on Sulphatases \\ 20. ENZYMIC CLEAVAGE OF ARYL HYDROGEN SULPHATES IN THE PRESENCE OF $\mathrm{H}_{2}{ }^{18} \mathrm{O}^{*}$
}

\author{
BY B. SPENCER \\ Division of Cancer Research, Washington University Medical School, St Louis, Missouri, \\ and Department of Biochemistry, University of Wales, Cardiff $\dagger$
}

(Received 5 December 1957)

Two types of arylsulphatase have been recognized (Dodgson \& Spencer, 1957a), the distinction between them being based on their relative substrate affinities and their behaviour towards various inhibitors. Type I arylsulphatases have an appreciable activity towards monopotassium $p$ nitrophenyl sulphate (NPS) and monopotassium $p$-acetylphenyl sulphate (APS) but are less active towards dipotassium 2-hydroxy-5-nitrophenyl sulphate (nitrocatechol sulphate, NCS). Type II enzymes have the reverse specificity, being invariably highly active towards NCS but only feebly active towards NPS and APS. The arylsulphatases are widely distributed in nature but so far only vertebrates are known to possess both type $I$ and type II enzymes simultaneously.

* Part 19: Dodgson \& Wynn (1958).

$\uparrow$ Present address.
The premises on which speculations about the function of these two types of arylsulphatase may be based are few. The fundamental issue, which has not yet been decided, is whether the enzymes exert a purely hydrolytic role or whether this is only a reaction in vitro and that in vivo they actually act as transferases. Two transferring activities can be envisaged involving the transfer of either the phenol or the sulphate group. In order to decide which of these reactions may be possible, the position of cleavage of arylsulphates by arylsulphatases has been studied by hydrolysis of the substrates in $\mathrm{H}_{2}{ }^{18} \mathrm{O}$ followed by isolation of the liberated sulphate and assay of its ${ }^{18} \mathrm{O}$ content. Cleavage of the $\mathrm{C}-\mathrm{O}$ bond (1) will yield inorganic sulphate containing no ${ }^{18} \mathrm{O}$, whereas if the $\mathrm{O}-\mathrm{S}$ bond is split (2) the ${ }^{18} \mathrm{O}$ content of the liberated sulphate will be one-quarter of the atoms per cent 